\title{
A Liquid Chromatography Procedure for Analysis of Nicotine on Cellulose Acetate Filters *
}

\author{
by C. R. Green, F. W. Conrad, Jr., K. A. Bridle and M. F. Borgerding \\ Research and Development Department, R. J. Reynolds Tobacco Company, \\ Winston-Salem, North Carolina, U.S.A.
}

\section{SUMMARY}

A procedure has been developed for filter analysis whereby the cellulose acetate is dissolved in acetonitrile to release any trapped nicotine. Dissolving the filter eliminates time consuming steam distillation or solvent extraction steps and assures that the recovery of nicotine is complete. After the filter is dissolved, the cellulose acetate is precipitated by addition of an aminephosphate buffer and an aliquot of the filtered solution is analyzed by high-pressure liquid chromatography (HPLC).

Two methods of HPLC analysis are described. In both cases the separation is achieved on a cyano-bonded silica column and detection is by ultraviolet absorption at $254 \mathrm{~nm}$. Different mobile phases are used in the two methods. In the first procedure, a diethylaminephosphate buffer at $\mathrm{pH} 7.56$ is used while in the second procedure, a dimethylamine-phosphate buffer at $\mathrm{pH} 3.00$ is used. Analytical results are equivalent for both chromatographic methods, but the second procedure may offer extended analytical column life. Results of a study relating the structure of the amine in the mobile phase to nicotine retention are presented.

The amount of nicotine trapped on cellulose acetate filters during smoking was determined with increasing intervals between smoking and analysis. These results demonstrate that nicotine is stable on filters and previous problems of analysis were caused by difficulty in removal from aged filters.

\section{ZUSAMMENFASSUNG}

Es wird über eine neue Methode zur Untersuchung von Zigarettenfiltern berichter, bei der das gesamte im Filter retinierte Nicotin durch Lösen des Celluloseacetates in Acetonitril freigesetzt wird. Das Auflösen des Filters erspart zeitaufwendige Wasserdampfdestillations- oder Lösungsmittelextraktionsschritte und gewährleistet eine vollständige Rückgewinnung des Nicotins. Nach dem Auflösen des Filters wird das Celluloseacetat durch $\mathrm{Zu}$ gabe eines Amin/Phosphat-Puffers ausgefält. Ein aliquoter Teil der filtrierten Lösung wird mittels Hochdruckflüssigchromatographie (HPLC) analysiert.

Die Hochdruckflūssigchromatographie ist auf $z$ weierlei Art durchführbar. In beiden Fällen erfolgt die Trennung an einer cyangebundenen Silikasäule und die UVDetektion bei einer Wellenlänge von $254 \mathrm{~nm}$. Als mobile Phase wird im einen Fall ein Diethylamin/Phosphat-Puffer mit einem $\mathrm{pH}$-Wert von 7,56 und im anderen Fall ein Dimethylamin/Phosphat-Puffer mit einem $\mathrm{pH}$-Wert von 3,00 verwendet. Die Analyseergebnisse sind bei beiden Chromatographie-Varianten gleich, wobei die Sãule bei der letztgenannten Art etwas lầnger benutzt werden kann. Es wurde untersucht, welche Bedeutung die in der mobilen Phase verwendete Aminstruktur für die Nicotinretention hat; die Ergebnisse werden dargelegt.

\footnotetext{
* Presented at the Coresta Symposium held in Winston-Salem, North Carolina, in November 1982.

Received: 21st March 1984 - accepted: 19 rh October 1984.
} 
Die im Celluloseacetatfilter retinierte Nicotinmenge wurde in Abhängigkeit vom Zeitintervall zwischen Abrauchen und Analyse bestimmt. Es zeigte sich, daß das Nicotin im Filter stabil ist und $\mathrm{da} B$ in früheren Untersuchungen aufgetretene Probleme darauf zurückzuführen sind, daß es sich bei gealtertem Filter schwerer extrahieren läßt.

\section{RÉSUME}

Ce rapport concerne une nouvelle méthode d'examen des filtres de cigarettes qui permet de libérer toute la nicotine retenue dans le filtre par dissolution de l'acétate de cellulose dans l'acétonitrile. La dissolution du filtre évite d'avoir recours à des procédés demandant beaucoup plus de temps, comme l'entraînement à la vapeur d'eau ou l'extraction par solvant, tout en garantissant la récupération intégrale de la nicotine. Après la dissolution du filtre, l'acétate de cellulose est précipité par addition d'une solution tampon amino-phosphatée. Une partie aliquote de la solution filtrée est analysée par chromatographie en phase liquide à haute pression (HPLC).

La chromatographie en phase liquide à haute pression peut être effectuée de deux façons. Dans les deux cas, la séparation est réalisée dans une colonne de silice cyanoliée, et la détection UV à une longueur d'onde de 254 nm. On utilise comme phase mobile dans un cas un tampon de phosphate de diéthylamine à un $\mathrm{pH}$ de 7,56 et, dans l'autre, un tampon de phosphate de diméthylamine à un $\mathrm{pH}$ de 3,00 . Quelle que soit la méthode employée, les résultats de l'analyse sont équivalents; la colonne peut servir un peu plus longtemps dans le cas de la seconde méthode. Une étude, dont les résultats sont présentés, a porté sur la relation existant entre la structure de l'amine utilisée dans la phase mobile et la rétention de la nicotine.

La quantité de nicotine retenue dans le filtre d'acétate a été déterminée en fonction de l'intervalle de temps sêparant le fumage de l'analyse. Il en résulte que la quantité de nicotine contenue dans le filtre est stable et que les problèmes qui s'étaient posés lors d'examens effectués dans le passé, étaient imputables au fait qu'il est difficile d'extraire la nicotine de filtres ayant vieilli.

\section{INTRODUCTION}

A major motivation for development of this procedure was to determine if nicotine collected on cellulose acetate filter material during smoking is stable.

Nicotine is an important constituent of tobacco and tobacco smoke. Because of this importance numerous analyses for this alkaloid have been developed. Procedures for measurement of leaf and smoke nicotine are well established and their accuracy and reliability well known. Analyses of nicotine deposited on cellulose acetate filters are less well developed; however, these measurements are important for studying filtration efficiency and human smoking. Procedures used for determination of filter nicotine include solvent extraction, steam distillation, or a combination of these methods. Most of these procedures require removing nicotine from the physically intact filter. They are time consuming and sometimes unreliable. For instance, Obnisbi and co-workers (1) have reported that nicotine collected on butt filter tips is not completely extracted by isopropyl alcohol. However, in a model experiment in which pure nicotine was adsorbed by a filter tip, nicotine was completely extracted. They suggested that some substance in cigarette smoke is interfering with this extraction. In our laboratory, we found that the age of the filter butts prior to extraction with an organic solvent is a major variable. Butts extracted soon after smoking give higher nicotine values than samples aged before extraction. Two reasons were proposed for this difference. Either nicotine is unstable on filter material or it migrates into the cellulose acetate fiber and becomes more difficult to remove upon aging. If migration into the filter tow is the problem, an analysis which dissolves the cellulose acetate would give more consistent results. A Coresta procedure has previously been published whereby cellulose acetate filters are dissolved in acetone prior to steam distillation for the analysis of nicotine (2). Also, Curran and Miller (3) have removed ${ }^{14} \mathrm{C}$-labeled materials from filters prior to scintillation spectrometry analysis by dissolving the cellulose acetate in a methylene chloride - methanol solution. This was done to insure that removal of the labeled material from the filter was complete.

\section{EXPERIMENTAL}

\section{Sample Preparation}

The filter butts from five cigarettes are placed in a $125 \mathrm{ml}$ Erlenmeyer flask. To this flask is added $50 \mathrm{ml}$ of acetonitrile (Burdick and Jackson, distilled in glass). The flask is shaken on a mechanical shaker until the cellulose acetate is dissolved. Fifty milliliters of a $0.08 \mathrm{M}$ diethylamine-phosphate buffer is added to the dissolved filter solution. If other buffers are used as the mobile phase in the HPLC, they replace the $0.08 \mathrm{M}$ diethylamine-phosphate buffer for sample preparation. The combined acetonitrile-buffer solution is shaken on a mechanical shaker until precipitation of the cellulose acetate is complete.

The suspension is filtered first through folded filter paper (Schleicher and Schnell (No. 588)) and a $4 \mathrm{ml}$ aliquot of this filtrate is further filtered through a Millipore Model FHLP $01300(0.5 \mu \mathrm{m})$ disposable filter. A $15 \mu$ aliquot of this solution is analyzed by HPLC.

Estimated time for sample preparation is $10-15 \mathrm{~min}$ utes. However, a number of samples may be prepared simultaneously. 
Flgure 1.

Filter butt nicotine analysis with a moblle phase of $80 \%$ 0.08 m dlethylamine-phosphate buffer and $20 \%$ acetonitrlle.

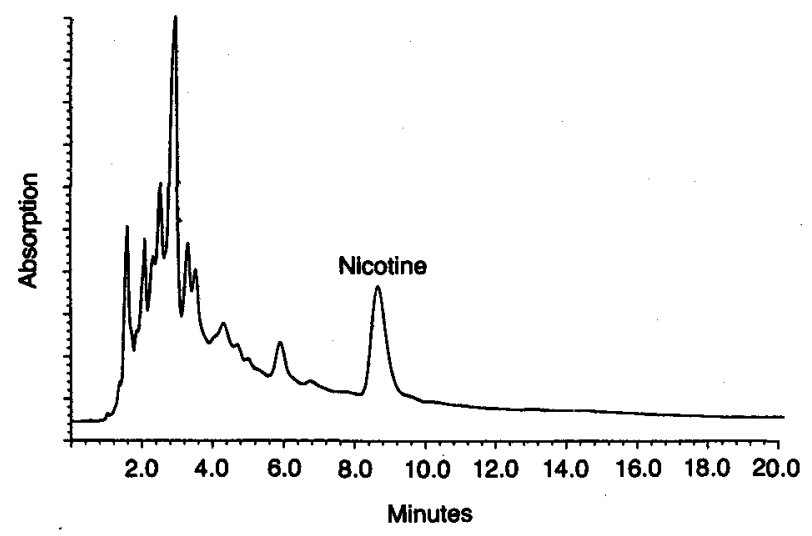

Figure 2.

Filter butt nicotine analysis with a moblle phase of $70 \%$ 0.01 m dimethylamine-phosphate buffer and $30 \%$ acetonitrlle.

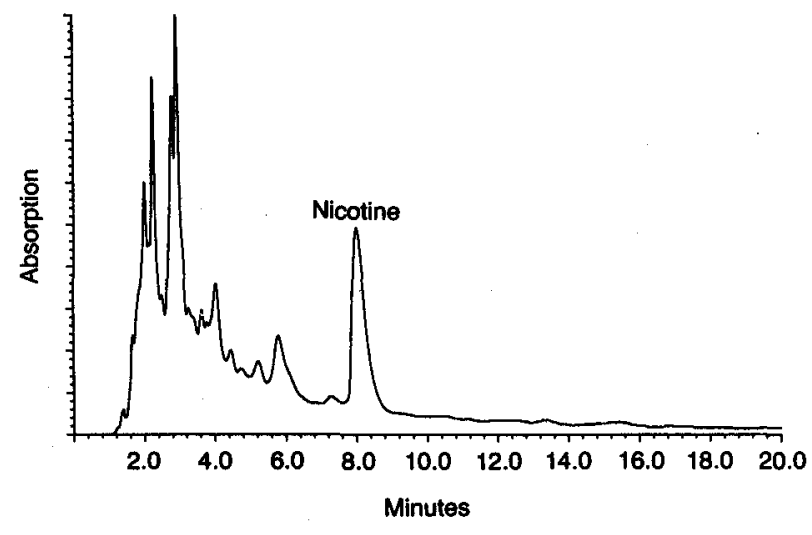

\section{Nicotine Standard Preparation}

An external standard is prepared by addition of $3.776 \mathrm{mg}$ nicotine (Eastman, $99 \%$ pure) to a $50 \mathrm{ml}$ acetonitrile solution of five unused cellulose acetate filters. Addition of the buffer and filtration are the same as in sample preparation.

Preparation of $0.08 \mathrm{M}$ dietbylamine-phosphate buffer at $p H$ 7.56: Thirty $\mathrm{ml}$ of diethylamine (Aldrich, reagent grade) is added to 3.51 of distilled water. This solution is adjusted to $\mathrm{pH} 7.56$ (4) by addition of $85 \%$ phosphoric acid (Mallinckrodt, ACS grade).

Preparation of $0.01 \mathrm{M}$ amine-phosphate buffer at $\mathrm{pH} 3.0$ : The procedure described below is generalized for the preparation of most amine-phosphate buffers. For example, if a $0.01 \mathrm{~m}$ dimethylamine buffer is desired, then dimethylamine would be used as the amine in the procedure.
Weigh one-tenth mole of amine into a $100 \mathrm{ml}$ flask and add $70 \mathrm{ml}$ of distilled water. Adjust the $\mathrm{pH}$ to 2.5 with $85 \%$ phosphoric acid and dilute to $100 \mathrm{ml}$ with water to prepare a $1.0 \mathrm{M}$ stock solution. The $0.01 \mathrm{~m}$ aminephosphate buffer is prepared by diluting $10 \mathrm{ml}$ of the stock solution to one liter with distilled water. This procedure produces a buffer of $\mathrm{pH} 3.0$ when dimethylamine is the amine used.

\section{HPLC Conditions for \\ 0.08 M Diethylamine-Phosphate Buffer at $p H$ 7.56: \\ Pump: Waters Associates (6000A) \\ Column: \\ Waters Associates (RCM-CN: $10 \mu \mathrm{m}, 8 \mathrm{~mm}$ inside diameter) \\ Mobile phase: $\quad 80 \% 0.08 \mathrm{M}$ diethylamine-phos- phate buffer at $\mathrm{pH} 7.56$ and $20 \%$ acetonitrile}

Flow rate: $\quad 2.0 \mathrm{ml} / \mathrm{min}$

Detector: fixed wavelength at $254 \mathrm{~nm}$ (UV)

Injection volume: $15 \mu \mathrm{l}$

Analysis time: 12 minutes

HPLC Conditions for

0.01 M Dimethylamine-Phosphate Buffer at $p H$ 3.0:

Mobile phase: $\quad 70 \% 0.01 \mathrm{~m}$ dimethylamine-phosphate buffer at $\mathrm{pH} 3.0$ and $30 \%$ acetonitrile

All other chromatographic conditions are the same.

Examples of chromatograms for filter butt nicotine analysis with the two different mobile phases are shown in Figures 1 and 2.

\section{RESULTS AND DISCUSSION}

\section{Sample Preparation}

In many ways, the development of the sample preparation procedure is based upon conditions necessary for the HPLC analysis. For instance, it is desirable that the sample be in a solution similar to the HPLC mobile phase. When the amine-phosphate buffer is added to the sample, the cellulose acetate is precipitated from solution and removed by filtration. Water can be used in place of the buffer to precipitate the cellulose acetate, but an unfilterable gel is formed. Precipitation and removal of the cellulose acetate are important for protection of the chromatographic system, but it also appears that the combination of acetonitrile and amine-phos- 
Table 1.

Comparison of nicotine recoverles from solutions of acetonltrlle and acetonitrile plus diethylamine-phosphate buffer.

\begin{tabular}{c|c|c}
\hline \multirow{2}{*}{$\begin{array}{c}\text { Sample } \\
\text { No. }\end{array}$} & Acetonitrile & Acetonitrile plus buffer \\
\cline { 2 - 3 } & $\begin{array}{c}\text { nicotine } \\
\text { (mg/filter) }\end{array}$ & $\begin{array}{c}\text { nicotine } \\
\text { (mg/filter) }\end{array}$ \\
\hline 1 & 0.60 & 0.68 \\
2 & 0.77 & 0.91 \\
3 & 0.43 & 0.68 \\
4 & 0.53 & 0.74 \\
5 & 0.47 & 0.79 \\
6 & 0.50 & 0.91 \\
7 & 0.54 & 0.71 \\
8 & 0.52 & 0.80 \\
9 & 0.54 & 0.68 \\
10 & 0.42 & 0.82 \\
\hline Mean & 0.53 & 0.77 \\
Relative standard & & 11.6 \\
deviation (\%) & 18.7 & \\
\hline
\end{tabular}

* Relative standard deviation (\%) - standard deviation $\times 100 /$ mean.

phate buffer gives higher recovery of nicotine than acetonitrile alone. This is shown by the results in Table 1.

\section{The Liquid Chromatograpby Procedure}

Development of the liquid chromatographic procedure for analysis of filter butt nicotine is based upon earlier work on tobacco alkaloids by Piade and Hoffmann (4). They used reverse-phase chromatography on an octadecylsilane-modified silica column with a mobile phase consisting of acetonitrile and a $0.07 \mathrm{~m}$ triethylamine-phosphate buffer at $\mathrm{pH} 7.56$. We found that for filter nicotine analysis a cyano-bonded silica column and solvent system consisting of acetonitrile and $0.08 \mathrm{M}$ diethylamine-phosphate buffer at $\mathrm{pH} 7.56$ give more symmetrical chromatographic peaks.

Quantitation is achieved by an external standard method in which a known amount of nicotine is added to a solution of five unused filters dissolved in $50 \mathrm{ml}$ acetonitrile. Blanks have been run on unused filters to insure that there is no interfering material from that source. Also, experiments have been performed which

\section{Table 2.}

Retention of nicotine versus structure of amine used in a moblle phase of $0.01 \mathrm{~m}$ amine-phosphate in $80 \%$ water and $20 \%$ acetonitrile at pH 3.0.

\begin{tabular}{l|c}
\hline \multicolumn{1}{c|}{ Amine } & $\begin{array}{c}\text { Retention time of nicotine } \\
\text { (min) }\end{array}$ \\
\hline Di-n-butyl & 2.39 \\
Triethyl & 4.42 \\
Diethyl & 6.67 \\
Dimethyl & 10.10 \\
Ammonium phosphate & 15.89 \\
\hline
\end{tabular}

show that, when nicotine is injected into unused filters, the recovery is complete. Detector response is linear over the range of $0.1-100 \mathrm{mg}$ nicotine per sample.

Although no problems in column life have been experienced, the $7.56 \mathrm{pH}$ of the mobile phase is dangerously close to the column limit of $\mathrm{pH} 8.0$ recommended by the column manufacturer. Waters Associates (5) have published procedures for analysis of amines with a mobile phase of acetonitrile and di- $n$-butylaminephosphate buffer at $\mathrm{pH}$ 3.0. This system does not work for filter butt analysis because the nicotine is not well separated from other smoke constituents which absorb at $254 \mathrm{~nm}$. A study of nicotine retention versus the structures of amine used in the buffer showed that the elution of nicotine relative to other smoke constituents can be modified. Results of this study are shown in Table 2.

Of course, the mechanism by which nicotine is retained in these chromatographic systems is quite complex and not well understood, but the bulk of the amine hydrocarbon group may interfere with interactions between the sample and surface of the column material. Thus, as the amine hydrocarbon group becomes smaller, interaction between nicotine and column material increases and retention is longer. As a result of this study, dimethylamine-phosphate buffer was found to give excellent separation of nicotine from other smoke components in filter nicotine analysis. Details of sample preparation are the same for both buffers except in one procedure $0.08 \mathrm{M}$ diethylamine-phosphate at $\mathrm{pH} 7.56$ is used while in the other procedure $0.01 \mathrm{M}$ dimethylamine-phosphate buffer at $\mathrm{pH} 3.0$ is used.

Analysis of filter butt nicotine is equivalent with either of the amine-phosphate buffer systems described. Because of its lower $\mathrm{pH}$, the acidic buffer may offer an improvement in analytical column life, but this has not been demonstrated in practice. For the remaining discussion, data are presented that have been generated from both procedures. Since the procedures are equivalent, no effort is made to differentiate the results based upon analysis method.

\section{Analytical Results}

To establish reproducibility of the chromatographic analysis, one sample of filter butts was analyzed five times. These results are shown in Table 3. These data show that the details of the chromatographic analysis including injection, chromatography, and detection are very reproducible. Variation in the analysis of filter butt nicotine from unselected cigarettes was established by smoking 50 cigarettes under standard smoking conditions and dividing the butts into 10 samples. Results of this analysis are shown in Table 4. They show that much more variation exists in the amount of filter nicotine due to sample non-uniformity than from the chromatography. To reduce sample variability, $50 \mathrm{ciga-}$ rettes selected in the pressure drop range of 129 $144 \mathrm{~mm}$ water at a flow rate of $17.5 \mathrm{~cm}^{3} / \mathrm{s}$ were 
Table 3.

Reproduclbility of chromatographic analysis.

\begin{tabular}{l|c}
\hline $\begin{array}{c}\text { Analysis } \\
\text { No. }\end{array}$ & \multicolumn{1}{c}{$\begin{array}{c}\text { Nicotine/filter } \\
\text { (mg) }\end{array}$} \\
\hline 1 & 0.704 \\
2 & 0.689 \\
3 & 0.701 \\
4 & 0.691 \\
5 & 0.696 \\
\hline Mean: & \\
Standard deviation: & $0.009 \mathrm{mg}$ \\
Relative standard & \\
deviation (\%) *: & 1.29 \\
\hline
\end{tabular}

* Relative standard devlation $(\%)$ - standard deviation $\times 100 /$ mean.

Table 4.

Analysls of filter butt nicotine from unselected cigarettes.

\begin{tabular}{|c|c|}
\hline $\begin{array}{l}\text { Analysis } \\
\text { No. }\end{array}$ & $\begin{array}{c}\text { Nicotine/filter } \\
\text { (mg) }\end{array}$ \\
\hline 1 & 0.796 \\
\hline 2 & 0.779 \\
\hline 3 & 0.727 \\
\hline 4 & 0.727 \\
\hline 5 & 0.607 \\
\hline 6 & 0.619 \\
\hline 7 & 0.671 \\
\hline 8 & 0.734 \\
\hline 9 & 0.719 \\
\hline 10 & 0.649 \\
\hline Mean: & $0.700 \mathrm{mg}$ \\
\hline Standard deviation: & $0.060 \mathrm{mg}$ \\
\hline $\begin{array}{l}\text { Relative standard } \\
\text { deviation }(\%)^{*} \text { : }\end{array}$ & 8.57 \\
\hline
\end{tabular}

* Relative standard deviation $(\%)$ - standard deviation $\times 100 /$ mean.

Table 5.

Analysis of filter nicotine from pressure drop selected cigarettes.

\begin{tabular}{c|c}
\hline $\begin{array}{c}\text { Analysis } \\
\text { No. }\end{array}$ & $\begin{array}{c}\text { Nicotine/filter } \\
\text { (mg) }\end{array}$ \\
\hline 1 & 0.733 \\
2 & 0.727 \\
3 & 0.652 \\
4 & 0.699 \\
5 & 0.680 \\
6 & 0.731 \\
7 & 0.671 \\
8 & 0.681 \\
9 & 0.709 \\
10 & 0.686 \\
\hline \multicolumn{3}{c}{} \\
Mean: & $0.697 \mathrm{mg}$ \\
Standard deviation: & $0.028 \mathrm{mg}$ \\
Relative standard & \\
deviation (\%) *: & 4.02 \\
\hline
\end{tabular}

* Relative standard deviation (\%) - standard deviation $\times 100 /$ mean.
Table 6.

Analysis of nicotine on aged filter butt samples.

\begin{tabular}{l|c}
\hline \multicolumn{1}{c|}{ Age } & $\begin{array}{c}\text { Nicotine/filter * } \\
(\mathrm{mg})\end{array}$ \\
\hline Frest, room $\left(25^{\circ} \mathrm{C}\right)$ & $0.70 \pm 0.03$ \\
1-day, room $\left(25^{\circ} \mathrm{C}\right)$ & $0.69 \pm 0.03$ \\
3-day, room $\left(25^{\circ} \mathrm{C}\right)$ & $0.73 \pm 0.04$ \\
6-day, room $\left(25^{\circ} \mathrm{C}\right)$ & $0.71 \pm 0.03$ \\
30-day, room $\left(25^{\circ} \mathrm{C}\right)$ & $0.71 \pm 0.04$ \\
30-day, freezer $\left(-25^{\circ} \mathrm{C}\right)$ & $0.72 \pm 0.04$ \\
\hline
\end{tabular}

* Average of triplicate samples.

smoked and the filter butts analyzed. These data are shown in Table 5. The values in this table show that about one half of the sample variation for filter butt nicotine can be eliminated by pressure drop selection of the cigarettes. Undoubtedly, further improvement in sample variability could be made by weight as well as pressure drop selection of test cigarettes; however, this has not been necessary for our current studies.

\section{Nicotine on Aged Filter Butt Samples}

Earlier studies with a non-dissolving solvent extraction procedure showed that fresh filter butts give consistently higher levels of nicotine than similar aged samples. It was unknown whether nicotine is not stable on cellulose acetate containing other smoke constituents or whether the nicotine is merely more difficult to extract because of migration into the filter tow. Reaction with other smoke constituents might also make the aged filter butt nicotine more difficult to extract. To investigate the stability of filter butt nicotine, a sample of pressure-drop selected cigarettes (122-144 $\mathrm{mm}$ water) was smoked under standard Federal Trade Commission (FTC) smoking conditions. Butts were collected, randomized, and analyzed in triplicate after periods of one, three, six and thirty days at room temperature. Samples were also stored in capped vials at $-25^{\circ} \mathrm{C}$ for thirty days. Results of these analyses are shown in Table 6. These values show conclusively that nicotine trapped on cellulose acetate filters during the smoking of a cigarette is stable at room temperature. Interestingly enough, even though the 30-day room and freezer samples ranged in color from dark brown to light tan, the level of nicotine was the same. This color difference would indicate that smoke compounds other than nicotine are not stable for a long period. Problems that have been encountered with the analysis of aged filter butts by other methods apparently are due to incomplete extraction of the nicotine.

\section{Variation of Butt Nicotine with Puff Volume}

To further illustrate the utility of the method, a study was made of nicotine collected on the filter for ciga- 
Table 7.

Filter butt nicotine at varlous puff volumes.

\begin{tabular}{|c|c|c|}
\hline \multicolumn{3}{|c|}{ Puff volume $(\mathrm{ml})$} \\
\hline 20 & 35 & 65 \\
\hline
\end{tabular}

Filter nicotine (mg/filter):

$\begin{array}{lllr}\text { Brand A } & 0.64 \pm 0.04 & 0.77 \pm 0.05 & 1.07 \pm 0.08 \\ \text { Brand B } & 0.62 \pm 0.03 & 0.77 \pm 0.04 & 1.10 \pm 0.08 \\ & & & \\ \text { Smoke nicotine (mg/cigarette): } & & & 1.04 \pm 0.02 \\ \text { Brand A } & 0.68 \pm 0.01 & 1.12 \pm 0.03 & 1.53 \pm 0.04 \\ \text { Brand B } & 0.72 \pm 0.03 & 1.67 \pm 0.02\end{array}$

Filter efficlency (\%):

Brand A

Brand B

48

46
43

41
41

40 rettes smoked under standard smoking conditions of 2-second puff duration at an interval of once a minute but at puff volumes of 20,35 and 65 milliliters. Results of these analyses are shown in Table 7. Quite obviously, these data show that smoke nicotine increases with puff volume. Changing puff volume may also affect filter efficiency (6). A greater part of the nicotine is retained by the filter at lower puff volumes. However, for the products tested, changing the puff volume from 35 to $65 \mathrm{ml}$ did not greatly affect filter efficiency. Apparently, changes in filter efficiency are greatest at puff volumes less than 35 milliliters.

The data in Table 7 demonstrate at least one problem which may be encountered while attempting to relate the amount of nicotine a smoker receives to filter butt nicotine. Since filter efficiency changes with puff volume, the size of the smoker's puff can make considerable difference in the relationship between filter butt and smoke nicotine. Other human smoking parameters which may be important in the relationship between filter butt and smoke nicotine include puff frequency, duration, butt length, puff shape, and non-uniform frequency. All of these factors combine to make the prediction from filter butt analysis of nicotine received by a smoker only an approximation. More refined measurements of smoking parameters are necessary to correct filter butt values before accurate prediction of smoke nicotine can be made.

\section{REFERENCES}

1. Ohnishi, A., Y. Akinage, K. Kobayashi, M. Ishu, K. Maeda and M. Udhara: Gas chromatographic determination of nicotine removal of cigarette filters,
I. Determination of nicotine in main stream and butt filter tips; Nippon Sembai Kosha Chuo Kenkyusho Kenkya Hokoku 114 (1972) 97-104.

2. Einheitliche Vorschriften für die Analyse von Tabak und Tabakrauch, 4. Vorschrift für die Bestimmung des Nikotins im Tabak, im Tabakrauchkondensat und in Filtern (G. Lipp: Coresta Groupe Fumée, Paris 1963); Beitr. Tabakforsch. 3 (1965) 87-89.

3. Curran, J. G., Jr., and E. G. Miller, Jr.: Factors influencing the elution of high-boiling components of cigarette smoke from filters; Beitr. Tabakforsch. 5 (1969) 64-70.

4. Piade, J., and D. Hoffmann: Chemical studies on tobacco smoke, LXVII. Quantitative determination of alkaloids in tobacco by liquid chromatography; J. Liquid Chromatography 3 (1980) 1505-1515.

5. Waters Associates Technical Bulletin (1981): The separation of amines using the radial compression separation system.

6. Overton, J. R.: Filtration of cigarette smoke: Relative contributions of inertial impaction, diffusional deposition, and direct interception; Beitr. Tabakforsch. 7 (1973) 117-120.

Autbors' address:

Research and Development Department, $R . J$. Reynolds Tobacco Company,

Winston-Salem, North Carolina, 27102, U.S.A. 